\title{
Cardiac Leiomyosarcoma
}

National Cancer Institute

\section{Source}

National Cancer Institute. Cardiac Leiomyosarcoma. NCI Thesaurus. Code C5364.

An aggressive malignant smooth muscle neoplasm, arising from the heart. It is characterized by a proliferation of neoplastic spindle cells. 